\title{
Study on the Stability of Coffer Dams under the Action of Percolation Force
}

\author{
Wenbin Liü, 2, 3, 4, a, Ruiqi Zhang 1, 2, 3,4 \\ ${ }^{1}$ Tianjin Port Engineering Institute Co., Ltd. Of CCCC First harbor engineering Co., Ltd., Tianjin, \\ 300222, China \\ ${ }^{2}$ Key Laboratory of Port Geotechnical Engineering, Ministry of Communications, PRC, Tianjin, \\ 300222, China \\ ${ }^{3}$ Key Laboratory of Port Geotechnical Engineering of Tianjin, Tianjin, 300222, China \\ ${ }^{4}$ CCCC First Harbor Engineering Company Ltd., Tianjin, 300461, China \\ aliuwenbin3943@163.com
}

\begin{abstract}
Based on a cofferdam project of Dalian, the global stability of cofferdam structure under the action of percolation force is calculated by simulation analysis methods. The study results show that the action of percolation force can effectively increase the stability for the out-sea side, but at the same time, the safety factor of the in-sea side would be reduced and harm the stability of in sea side slope.
\end{abstract}

Keywords: percolation force, cofferdam structure, global stability, PLAXIS 3D finite element software.

\section{Introduction}

The cofferdam is the most commonly used structures in port engineering. The cofferdams can be used in soft soil, which can be used for the construction breakwaters and etc[1-2]. The cofferdam is a temporary structure built to enclose an area for excavation of foundation. Coffer dams are designed \& placed when the size of excavation is very large and sheeting and bracing system becomes difficult or uneconomical. Coffer dams are generally required for foundations of structures, such as bridge piers, docks, locks, and dams, which are built in open water. These are also used for underlying foundations on open land where there is a high ground water table. A coffer dam generally consists of a relatively impervious wall built around the periphery of the proposed excavation to prevent the flow of water into the excavation to prevent the flow of water into the excavation so that the foundation may be laid in dry condition.

This paper based on a cofferdam project of Dalian, calculate the global stability of cofferdam structure under the action of percolation force by simulation analysis methods. The study results show that the action of percolation force can effectively increase the stability for the out-sea side, but at the same time, the safety factor of the in-sea side would be reduced and harm the stability of in sea side slope. The high pressure jet grouting pile is good for the stability of cofferdam.

The foundation calculation PLAXIS 3D finite element software is used to calculate the global stability of the temporary cofferdam.

\section{Project Profile}

The project is located in the Ganjingzi district of Dalian city. The cofferdam is consisted of stone, there are rocks on the top of the cofferdam, and the soil foundation is weathered dolomite. In the middle of the cofferdam, high pressure jet grouting piles are used to prevent the sea water. The cofferdam is $16 \mathrm{~m}$ tall and the slope ratio is $1: 2$.

The calculation parameters are shown in Table 1. 
Table 1. Calculation Parameters

\begin{tabular}{|c|c|c|c|c|c|c|c|}
\hline \multirow[b]{2}{*}{ Material } & \multirow[b]{2}{*}{$\begin{array}{c}\text { Unit } \\
\text { weight } \\
/ \mathrm{kN} / \mathrm{m}^{3}\end{array}$} & \multirow[b]{2}{*}{$\begin{array}{c}\text { sub- } \\
\text { weight } \\
\mathrm{kN} / \mathrm{m}^{3}\end{array}$} & \multicolumn{2}{|c|}{ Shearing strength } & \multirow[b]{2}{*}{$\begin{array}{c}\text { stiffness } \\
/ \mathrm{MPa}\end{array}$} & \multirow[b]{2}{*}{$\begin{array}{l}\text { Passion } \\
\text { ratio }\end{array}$} & \multirow{2}{*}{$\begin{array}{c}\text { percolation } \\
\text { coefficient } \\
\mathrm{kx}=\mathrm{ky}=\mathrm{kz} \\
\mathrm{m} / \text { day }\end{array}$} \\
\hline & & & $\begin{array}{c}\text { cohesion } \\
\qquad / \mathrm{kPa}\end{array}$ & $\begin{array}{l}\text { internal } \\
\text { friction } \\
\text { angle }{ }^{\circ}\end{array}$ & & & \\
\hline rock & 17 & 10 & 0 & 38 & 9 & 0.3 & 0.01 \\
\hline stone & 16 & 10 & 0 & 35 & 9 & 0.3 & 0.01 \\
\hline $\begin{array}{l}\text { High pressure jet } \\
\text { grouting pile }\end{array}$ & 23 & 13 & - & - & 26 & 0.2 & $8.64 \mathrm{e}-3$ \\
\hline $\begin{array}{l}\text { Weathered } \\
\text { dolomite }\end{array}$ & 26.5 & 16.5 & 80 & 40 & 30 & 0.25 & $0.1 \mathrm{e}-3$ \\
\hline
\end{tabular}

The out-sea water level is $+1.85 \mathrm{~m}$, in-sea water level is- $14.2 \mathrm{~m}$. There are $50 \mathrm{kPa}$ uniform loads on the top of the cofferdam.

\section{Calculate Results}

PLAXIS 3D finite element software is used to calculate the global stability, the calculate model is shown in Figure 1. The model is $120 \mathrm{~m}$ long, $20 \mathrm{~m}$ wide and $80 \mathrm{~m}$ deep; There are $16.05 \mathrm{~m}$ water head between the out-sea side and in-sea side of the cofferdam. $50 \mathrm{kPa}$ uniform force is applied on the top of the cofferdam; the calculated parameters are shown in Table 1; Mohr-Coulomb Mode is used in the simulation.

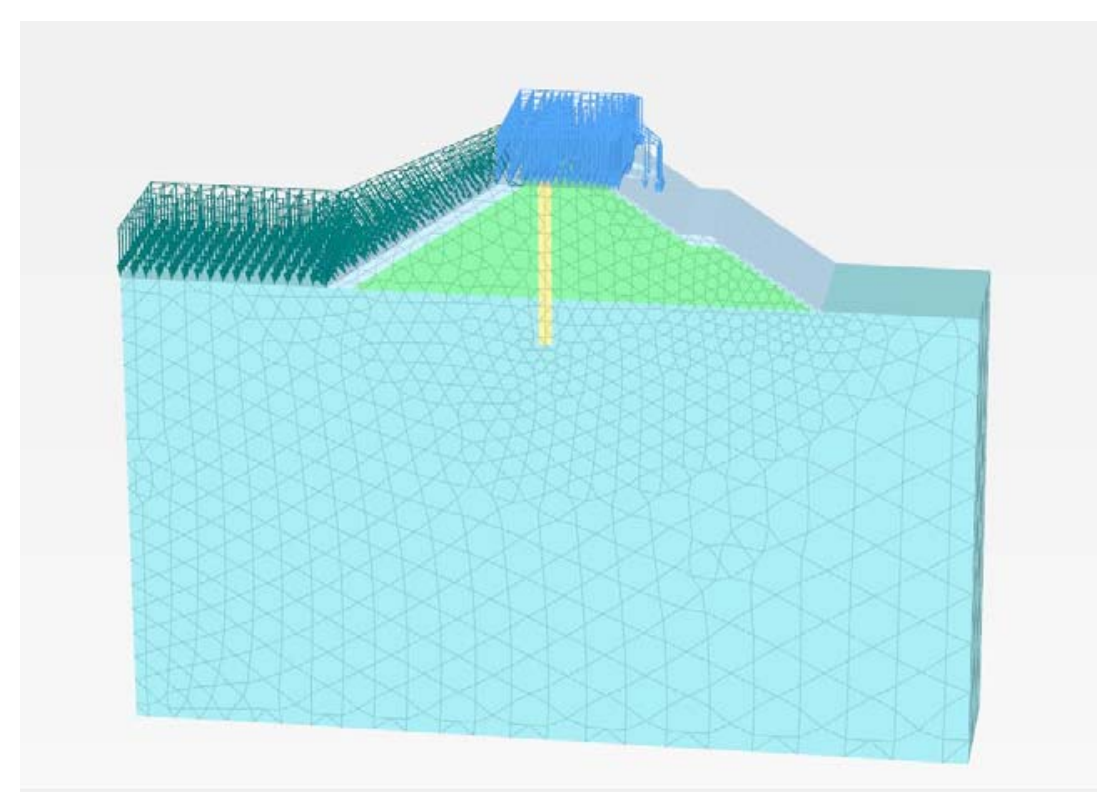

Figure 1. Deformation Meshes

The distribution of cofferdam's deformation is shown in Figure 2. 


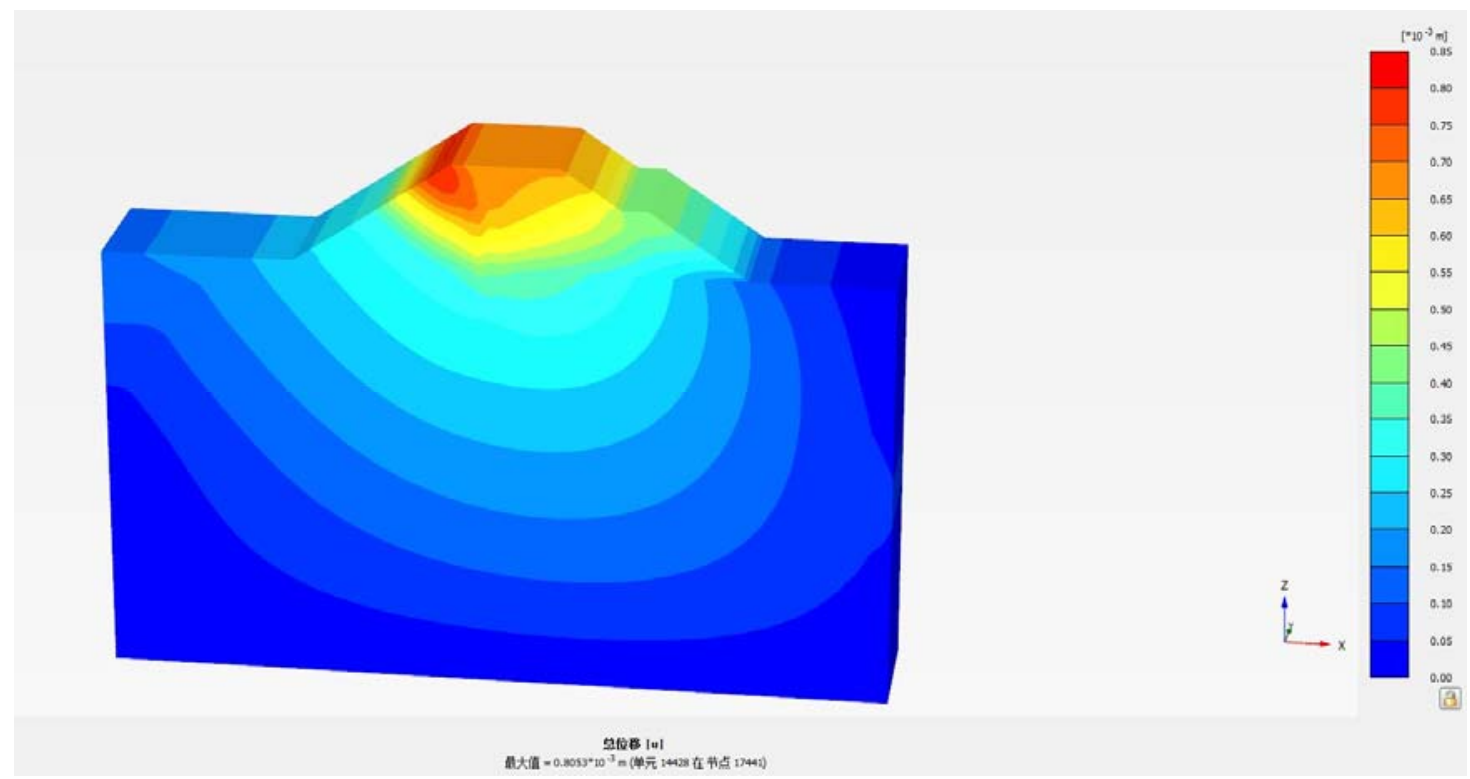

Figure 2. Distribution of Cofferdam’S Deformation

The Figure 2 shows that the max deformation of the cofferdam is about $0.8 \mathrm{~mm}$, which is small enough to keep the stability of the cofferdam. Due to the action of the percolation force, there are some deformations and pressure on the high pressure jet grouting pile, which are shown in Figure 3 and Figure 4.

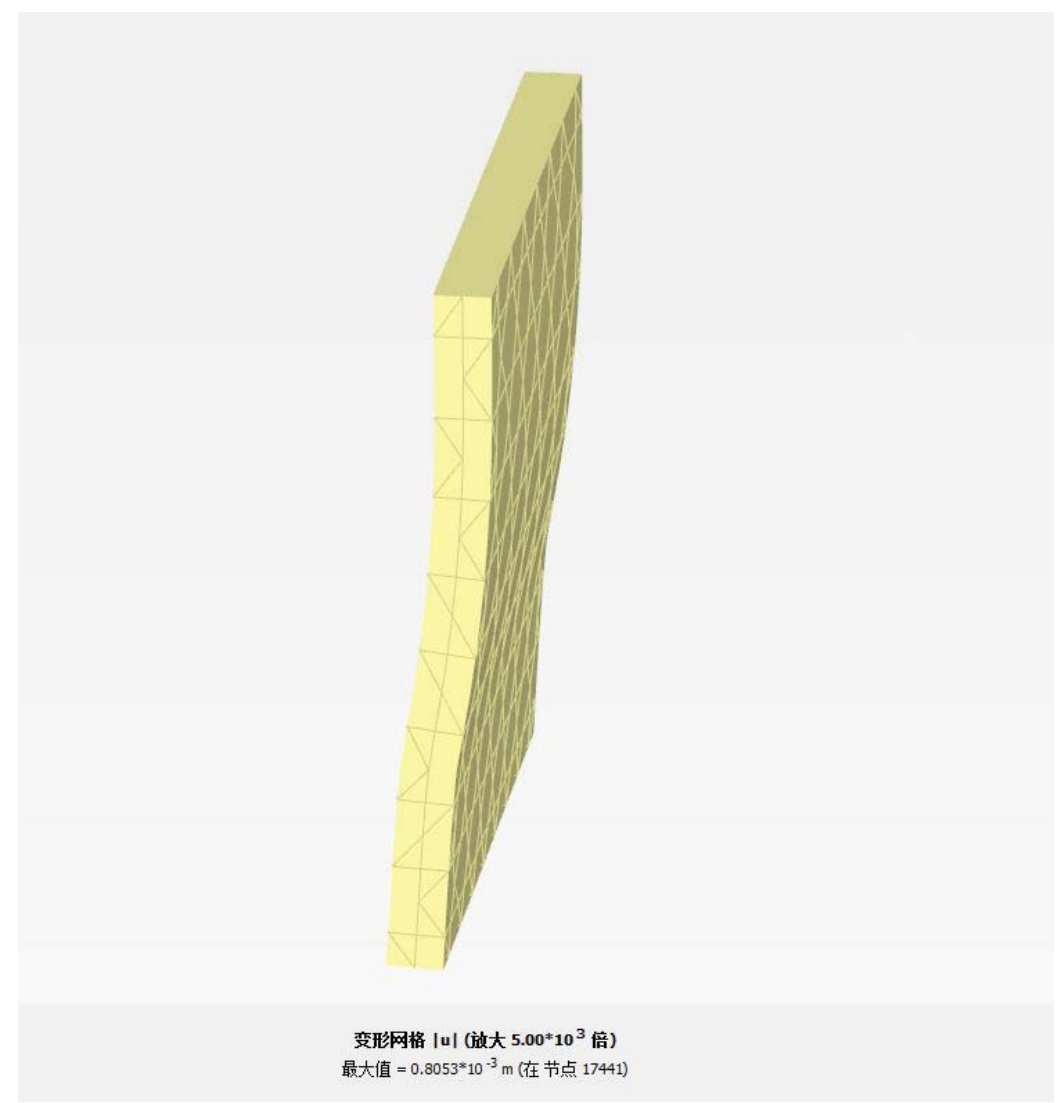

Figure 3. Deformation Meshes of High Pressure Jet Grouting Pile (Max=0.8 mm) 


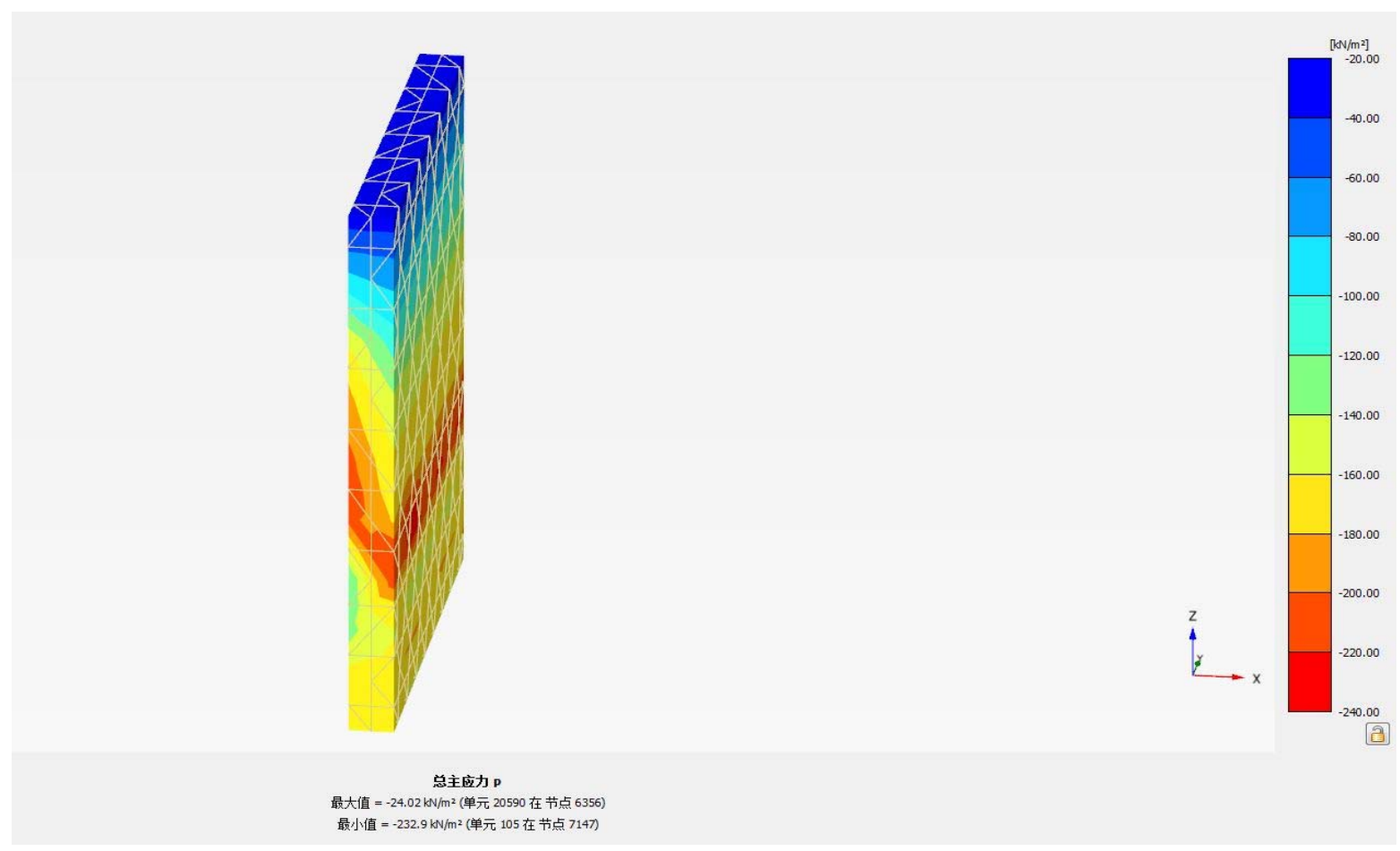

Figure 4. Distribution of High Pressure Jet Grouting Pile’S Stress

Figure 3 shows the deformation of the high pressure jet grouting pile and the max deformation is about $0.8 \mathrm{~mm}$. Figure 4 shows the stress of the high pressure jet grouting pile and the max stress is about $232.9 \mathrm{kPa}$ which is smaller than the breakdown stress.

In order to know the influence of the percolation force to the cofferdam stability, calculate the safety factor of considering the percolation force and not considering the percolation force. Put the results in Table 2.

Table 2. The Safety Factor in Different Calculate Condition

\begin{tabular}{|c|c|}
\hline Whether consider the percolation force & The safety factor \\
\hline no & 1.138 \\
\hline yes & 1.156 \\
\hline
\end{tabular}

Table 2 shows the safety factors in different calculate conditions. From Table 2, we can know that if the percolation force is not considered, the safety factor is 1.138 which is smaller than the value of considering the percolation force. Thus, the high pressure jet grouting pile is good for the stability of cofferdam.

\section{Summary}

PLAXIS 3D finite element software are used to calculate the global stability of the temporary cofferdam. The conclusions are as follow:

(1) When the percolation force is not considered, the dangerous sliding surface of the cofferdam is located on the out-sea side; the maximum safety factor is 1.138. When the percolation force is considered, the dangerous sliding surface of the cofferdam is located on the in-sea side; the maximum safety factor is 1.156 .

(2) Under the action of percolation force, the max stress of high pressure jet grouting pile is -$232.9 \mathrm{kPa}$, the max deformation is $0.8 \mathrm{~mm}$.

(3) The high pressure jet grouting pile is good for the stability of cofferdam. 


\section{References}

[1]. Rheological model of soft rock creep based on the tests on marl[J] . Zvonko Tomanovic. Mechanics of Time-Dependent Materials . 2006 (2)

[2]. Variable factor of safety in slope stability analysis. A.k.chugh. 1978. 